(c) Inra/Elsevier, Paris

Original article

\title{
Selection for reduced muscle glycolytic potential in Large White pigs. III. Correlated responses in growth rate, carcass composition and reproductive traits
}

\author{
Catherine Larzula*, Pascale Le Roy ${ }^{a}$, Jean Goguéb, \\ André Talmantc ${ }^{c}$ Gabriel Monin ${ }^{c}$, Pierre Sellier ${ }^{\mathrm{a}}$ \\ a Station de génétique quantitative et appliquée, Institut national \\ de la recherche agronomique, 78352 Jouy-en-Josas cedex, France \\ b Domaine de Galle, Institut national de la recherche agronomique, \\ 18520 Avord, France \\ c Station de recherches sur la viande, Institut national de la recherche agronomique, \\ Theix, 63122 Saint-Genès-Champanelle, France
}

(Received 25 May 1998; accepted 2 February 1999)

\begin{abstract}
A six-generation selection experiment comprising a selected (S) and a control line (C), and aiming at decreasing muscle glycolytic potential has been conducted in purebred Large White pigs presumably free of the $\mathrm{Hal}^{\mathrm{n}}$ and $\mathrm{RN}^{-}$ alleles. Both lines consisted of six to eight sires and around 40 dams per generation. Each dam produced two litters with replacement boars and gilts kept from the firstparity litters. The selection criterion in the $\mathrm{S}$ line was the in vivo glycolytic potential (IVGP) of the longissimus muscle, measured on a shot biopsy sample removed at about $75 \mathrm{~kg}$ live weight. Correlated responses to selection for low IVGP as well as heritabilities and genetic correlations with IVGP were estimated for average daily gain ( 6761 offspring from parities 1 and 2), ultrasonic backfat thickness (3 078 boars and gilts from parity 1 ), carcass composition traits (1 185 castrated males and gilts from parity 2), age at first oestrus (1084 gilts) and litter size and weight at birth, at 21 days of age and at weaning (917 litters). Heritability estimates of these traits were within the usual range of literature values. The estimates of genetic correlation $\left(r_{A}\right)$ with IVGP were $0.15 \pm 0.07$ for average daily gain, $-0.32 \pm 0.06$ for ultrasonic backfat thickness, $-0.20 \pm 0.10$ for carcass backfat thickness, $-0.24 \pm 0.09$ for weight
\end{abstract}

* Correspondence and reprints: Station d'amélioration génétique des animaux, BP 27, 31326 Castanet-Tolosan cedex, France

E-mail: larzul@toulouse.inra.fr 
of backfat, $0.18 \pm 0.09$ for carcass lean meat percentage, and $0.49 \pm 0.15$ for loin muscle area. In agreement with the $r_{A}$ estimates pertaining to carcass composition traits, the most pronounced correlated response to downward selection on IVGP was a decrease of carcass lean to fat ratio in the $\mathrm{S}$ line compared with the $\mathrm{C}$ line. Genetic trends per generation amounted to $-0.13,0.12$ and 0.16 phenotypic standard deviation units of lean meat percentage, backfat thickness and backfat weight, respectively. A negative $\mathrm{r}_{\mathrm{A}}$ estimate $(-0.29 \pm 0.11)$ was found between age at first oestrus and IVGP, but there was no evidence for significant genetic relationships with IVGP or noticeable correlated genetic trends in the $\mathrm{S}$ line, regarding litter size and weight traits. (c) Inra/Elsevier, Paris

pig / muscle glycolytic potential / selection experiment / carcass composition / reproductive traits

Résumé - Sélection pour abaisser le potentiel glycolytique du muscle chez le porc Large White. III. Réponses corrélatives pour la vitesse de croissance, la composition corporelle et les caractères de reproduction. Une expérience de sélection comportant une lignée sélectionnée (S) et une lignée témoin (C) et visant à abaisser le potentiel glycolytique du muscle a été conduite pendant six générations chez des porcs de race pure Large White français présumée indemne des allèles $\mathrm{Hal}^{\mathrm{n}}$ et $\mathrm{RN}^{-}$. L'une et l'autre lignée comprenait six à huit pères et environ 40 mères par génération. Chaque mère produisait deux portées, et le renouvellement se faisait parmi les verrats et truies issus des $1^{\text {res }}$ portées. Le critère de sélection dans la lignée $\mathrm{S}$ était le potentiel glycolytique in vivo (IVGP) du muscle longissimus, mesuré sur un échantillon prélevé par biopsie à un poids vif voisin de $75 \mathrm{~kg}$. Les réponses corrélatives à la sélection pour un faible IVGP ainsi que les héritabilités et les corrélations génétiques avec le IVGP ont été estimées pour le gain moyen quotidien (6 761 descendants des $1^{\text {res }}$ et $2^{\text {es }}$ portées), l'épaisseur de lard dorsal mesurée aux ultrasons ( 3078 verrats et truies des $1^{\text {res }}$ portées), les caractères de composition de la carcassse ( 1185 mâles et femelles des $2^{\text {es }}$ portées), l'âge au $1^{\text {er }}$ œstrus ( 1084 femelles) et la taille et le poids de la portée à la naissance, à $21 \mathrm{j}$ et au sevrage (917 portées). Les estimées des héritabilités de ces caractères ont été du même ordre de grandeur que les valeurs usuelles de la littérature. Les estimées des corrélations génétiques avec IVGP ont été de $0,15 \pm 0,07$ pour le gain moyen quotidien, de $-0,32 \pm 0,06$ pour l'épaisseur de lard dorsal mesurée aux ultrasons, $-0,20 \pm 0,10$ pour l'épaisseur de lard dorsal mesurée sur la carcasse, $-0,24 \pm 0,09$ pour le poids de la bardière, $0,18 \pm 0,09$ pour la teneur en tissu maigre de la carcasse et $0,49 \pm 0,15$ pour la surface de noix de côtelette. En accord avec les corrélations génétiques concernant les caractères de composition de la carcasse, la plus forte réponse corrélative à la sélection pour un faible IVGP a été une diminution du rapport muscle/gras de la carcasse dans la lignée $\mathrm{S}$ par rapport à la lignée témoin. Les tendances génétiques par génération se sont élevées respectivement à $-0,13,0,12$ et 0,16 unité d'écart-type phénotypique pour le pourcentage de muscle, l'épaisseur de lard dorsal et le poids de la bardière. Une corrélation génétique négative $(-0,29 \pm 0,11)$ a été trouvée entre l'âge au $1^{\mathrm{er}}$ œstrus et IVGP, mais il n'y a eu aucune indication d'association génétique significative avec IVGP ou de réponses corrélatives à la sélection notables dans la lignée $\mathrm{S}$ en ce qui concerne les caractères de taille et de poids de la portée. (c) Inra/Elsevier, Paris

porc / potentiel glycolytique musculaire / expérience de sélection / composition de la carcasse / caractères de reproduction 


\section{INTRODUCTION}

In past French pig breeding programmes, selection for higher growth rate, better feed efficiency and lower backfat thickness gave rise to a slight deterioration of meat technological quality [25], in particular the technological yield of cured-cooked ham processing, which is among the most important traits for the pork processing industry in France [22]. Thus, from the mid-1980s, a meat quality index (IQV) calculated from three post mortem measurements (ultimate $\mathrm{pH}$, colour and water-holding capacity) was incorporated into the overall breeding objective with the constraint of keeping constant meat technological quality [30]. The in vivo measurement of muscle glycolytic potential [18] $[21,32]$ has been put forward as a possible alternative selection criterion for improving technological meat quality. However, before using such a selection criterion, its genetic relationships with other selected traits need to be accurately known. It has been established in a selection experiment [20] that the in vivo glycolytic potential of longissimus muscle (IVGP) is moderately heritable and can be reduced in a Large White population presumably free of the $\mathrm{Hal}^{\mathrm{n}}$ and $\mathrm{RN}^{-}$alleles. In both selected and control lines of this experiment, a number of growth, carcass composition and reproductive traits was measured over the six generations of selection in order to assess the genetic relationships between IVGP and these traits (genetic correlations and correlated responses to downward selection on IVGP). Results obtained in that respect are reported in the present article.

\section{MATERIALS AND METHODS}

\subsection{Experimental animals}

The selection experiment was carried out over six generations of selection for reducing muscle glycogen content as assessed by IVGP. Details of this experiment are given by Le Roy et al. [20]. Two lines, constituted from a common breeding stock of Large White pigs, were bred contemporaneously. One line ( $\mathrm{S}$ line) was selected downward on IVGP measured in the longissimus muscle $[21,32]$. The other line (C line) was randomly bred. The experiment was conducted over six generations.

Both lines consisted of six to eight sires and 35 to 40 dams per generation. Each dam was expected to produce two litters. Selection was made among male and female offspring from first-parity litters. Castrated males and females from second-parity litters (about three animals per litter), were slaughtered in a commercial abattoir at around $100 \mathrm{~kg}$ live weight as described by Larzul et al. [17] and were recorded for various carcass measurements.

\subsection{Measurements}

\subsubsection{Growth and carcass composition traits}

All available offspring from first- and second-parity litters were first reared in a post-weaning unit, then moved at around $20 \mathrm{~kg}$ live weight to open-front fattening buildings in which they were housed in pens of ten animals from the 
same line and had ad libitum access to a commercial diet (self feeders). They were recorded for average daily gain from about $25 \mathrm{~kg}$ live weight to about $100 \mathrm{~kg}$ live weight. Boars and gilts from first-parity litters were measured for ultrasonic backfat thickness at an average live weight of $90.9 \pm 3.9 \mathrm{~kg}$. The average value of the six measurements taken on both sides of the animal at the shoulder, back and rump levels [6] was used for analysis.

Three animals (at least one castrated male and one female) per secondparity litter were recorded for carcass measurements on the day after slaughter (average slaughter live weight: $100.8 \pm 3.2 \mathrm{~kg}$ ). Dressing percentage was calculated as the ratio of cold carcass weight (with head and feet) to unfasted live weight. Carcass length (from the first cervical vertebra to the anterior edge of the pubial symphysis) and midline backfat thickness (at the shoulder, back and rump levels [24]) were measured on the right half-carcass. Then, this halfcarcass was divided into seven joints according to the commercial standardised cutting method described by Ollivier [24]. Each joint was weighed and carcass lean meat content (LMC) was estimated from three joint weights using the following equation [29]:

$\mathrm{LMC}=16.56+(71.6$ ham weight +83.0 loin weight -76.2 backfat weight)/half-carcass weight.

Loin eye area was measured by planimetry at the last rib level on one animal per litter, either a castrated male or a female. On the same animals, the right ham was trimmed (i.e. defatted and deboned), and the ham lean percentage was calculated as the ratio of trimmed ham to entire ham. Numbers of animals recorded for each group of traits are reported in table $I$.

Table I. Structure of the data set.

\begin{tabular}{lcc}
\hline Item & Selected line & Control line \\
\hline Number of sires & 48 & 55 \\
Number of litters & 231 & $289^{\mathrm{a}}$ \\
$\quad$ 1st parity & 207 & 190 \\
$\quad$ 2nd parity & & \\
Number of pigs & 1638 & $2045^{\mathrm{a}}$ \\
$\quad$ Average daily gain & 1621 & 1457 \\
$\quad$ 1st parity litters & 1339 & $1739^{\mathrm{a}}$ \\
$\quad$ 2nd parity litters & $608(232)$ & $577(222)$ \\
Ultrasonic backfat thickness (1st parity litters) & 366 & $635^{\mathrm{a}}$ \\
Carcass composition traits (2nd parity litters) & $\mathrm{b}$ & \\
Age at first oestrus of gilts & & \\
\hline
\end{tabular}

a These numbers include litters and pigs from the base population (G0); ${ }^{b}$ numbers for ham lean percentage and loin eye area in brackets.

\subsubsection{Reproductive traits}

Age at the first oestrus in gilts was determined by the occurrence of the standing reflex when exposed to a teaser boar. Daily oestrus detection began 
at 150 days of age and continued until 250 days of age. Females were kept to produce two litters. They were distributed into seven 3-week-spaced farrowing batches for each generation-parity combination. Litters were born in individual farrowing pens. Total number of piglets born, number of piglets born alive and number of piglets weaned, as well as litter weight at birth, at 21 days of age and at the weaning time (at around 28 days of age) were recorded at each farrowing (table I). In a few litters, adoptions of piglets were settled, and weaned piglets were attributed to their genetic dam in the present analysis.

\subsection{Statistical analysis}

Preliminary least square analyses were performed using the GLM procedure of SAS [27] in order to determine the fixed effects which should be taken into account in the following analyses.

Variance and covariance components were estimated using a restricted maximum likelihood (REML) procedure applied to a multiple-trait individual animal model.

The model for all production traits contained litter effect and additive breeding value as random effects. For average daily gain, the model included the fixed effects of sex and batch, and the weaning weight as a covariate. The model included the fixed effects of sex and day of measurement, and the live weight at measurement as a covariate for ultrasonic backfat thickness, and the fixed effects of sex and batch and the carcass weight as a covariate for carcass composition traits (for dressing percentage, the covariate was the slaughter live weight). For loin eye area and ham lean percentage (only one animal recorded per litter), the random litter effect was deleted from the model.

For reproductive traits, the fixed effects of farrowing batch and the covariate age at farrowing (except for age at first oestrus) were included in the model with additive breeding value included as a random effect.

All the ancestors of the tested animals, up to the grandparents of the animals of the base population from which the control and selected lines were derived, were taken into account in the pedigree file for establishing the numerator relationship matrix of the animals.

The inclusion of all traits in a single analysis was not feasible owing to computational limitations, and several analyses were performed. The estimation of genetic parameters was performed in a series of two-trait analyses for production traits including the selection criterion (IVGP) and another trait, and in a series of three-trait analyses for reproductive traits because records on first- and second-parity litters were considered as different traits. These analyses were performed with version 3.2 of the VCE computer package, using a quasi-Newton algorithm with exact first derivatives to maximize the log likelihood [23]. Approximate standard errors of variance components and genetic parameters were obtained from the inverse of an approximation of the Hessian matrix when convergence was reached [28]. Coheritabilities of all traits with IVGP were calculated from REML-estimated parameters. Coheritability of one trait with IVGP is the genetic correlation between both traits multiplied by the square root of the product of their heritabilities. Their standard errors were approximated from the standard errors of component parameters using the first-order term of a Taylor expansion. 
Additive breeding values were estimated in two-trait analyses with a BLUP (best linear unbiased prediction) methodology applied to an individual animal model as previously described for the REML analysis. The REML-estimated genetic parameters were used in the model. The analyses were performed using the PEST computer package [8]. Mean breeding values were calculated per line for each generation. When averaging breeding values for a trait, only individuals having a record for that trait were taken into account. The genetic trend was estimated by the linear regression of the difference between the mean breeding values of both lines (selected - control) on the generation number. For simplification, the approximate variances of the annual $(\mathrm{S}-\mathrm{C})$ differences were calculated for each trait with REML-estimated parameters, considering that animal breeding values were computed in univariate analyses [31]. Regression was constrained to pass through the origin because both lines were taken from the same base population, and each line difference was weighted by the inverse of its approximate sampling variance.

\section{RESULTS}

\subsection{Growth and carcass composition traits}

Heritability estimates (table II) for most performance test and carcass traits ranged from 0.3 to 0.5 , except for carcass dressing percentage, weight of head and shoulder joints. Genetic correlations with IVGP were positive for average daily gain, carcass lean content, ham lean percentage and loin eye area, but negative for backfat depths.

In response to downward selection on IVGP, average daily gain sharply increased in the selected line in the first two generations. Afterwards, the genetic difference between the two lines, however, tended to decrease (figure 1). Ultrasonic backfat thickness steadily increased in the selected line in comparison with the control line (figure 2), and the difference between the two lines reached 0.75 phenotypic standard deviation units of the trait in the last generation. Correlated responses in carcass backfat thickness, lean meat content, loin and backfat weights and loin eye area concur to show a decrease of carcass lean to fat ratio in the selected line compared with the control line.

\subsection{Reproductive traits}

The heritability values of reproductive traits are given in table III. For litter size and litter weight at birth, heritability values were higher for first-parity than for second-parity records. For litter weight at 21 days, heritability values were similar, and for litter weight at weaning, heritability value was higher for second-parity records. The genetic correlations of litter size or weight with IVGP were low and similar for both parities. Only genetic correlations of age and first oestrus and first-parity litter weight at weaning with IVGP were significant 
Table II. Phenotypic and genetic parameters, correlated genetic responses to selection for reduced IVGP, and coheritabilities with IVGP for growth rate and carcass composition traits.

\begin{tabular}{|c|c|c|c|c|c|c|}
\hline Trait & $\mu^{\mathrm{a}}$ & $\sigma_{\mathrm{p}}^{\mathrm{b}}$ & $h^{2 c}$ & $\mathrm{r}_{\mathrm{A}}{ }^{\mathrm{d}}$ & $\mathrm{R}^{\mathrm{e}}$ & $\mathrm{Co}-\mathrm{h}^{2 \mathrm{f}}$ \\
\hline $\begin{array}{l}\text { Average daily } \\
\text { gain }(\mathrm{g}) \\
\text { Ultrasonic } \\
\text { backfat } \\
\text { thickness }(\mathrm{mm})\end{array}$ & 806 & 2.3 & $0.38(0.02)$ & $-0.32(0.06)$ & $0.35(0.03)$ & $-0.11(0.02)$ \\
\hline $\begin{array}{l}\text { Dressing } \\
\text { percentage } \\
\text { Carcass }\end{array}$ & 76.4 & 1.8 & $0.11(0.04)$ & $0.18(0.14)$ & $-0.06(0.02)$ & $0.03(0.02)$ \\
\hline length (mm) & 957 & 26 & $0.51(0.05)$ & $-0.12(0.09)$ & $-2.2(0.7)$ & $-0.04(0.03)$ \\
\hline \multicolumn{7}{|c|}{ Backfat thickness (mm) } \\
\hline $\begin{array}{l}\text { neck } \\
\text { back } \\
\text { rump } \\
\text { average }\end{array}$ & $\begin{array}{l}40.9 \\
22.7 \\
24.4 \\
29.4\end{array}$ & $\begin{array}{l}6.2 \\
3.8 \\
4.9 \\
4.1\end{array}$ & $\begin{array}{l}0.33(0.04) \\
0.47(0.05) \\
0.40(0.05) \\
0.43(0.05)\end{array}$ & $\begin{array}{l}-0.16(0.10) \\
-0.15(0.10) \\
-0.23(0.10) \\
-0.20(0.10)\end{array}$ & $\begin{array}{l}0.30(0.17) \\
0.36(0.08) \\
0.78(0.08) \\
0.48(0.10)\end{array}$ & $\begin{array}{l}-0.05(0.03) \\
-0.05(0.03) \\
-0.07(0.03) \\
-0.07(0.03)\end{array}$ \\
\hline \multicolumn{7}{|c|}{ Weight of joints $(\mathrm{kg})$} \\
\hline head & 6.52 & 0.42 & $0.04(0.02)$ & $-0.01(0.19)$ & $0.012(0.005)$ & $0.00(0.03)$ \\
\hline feet & 1.09 & 0.08 & $0.40(0.05)$ & $-0.21(0.10)$ & $0.000(0.001)$ & $-0.07(0.02)$ \\
\hline backfat & 4.15 & 0.59 & $0.65(0.05)$ & $-0.24(0.09)$ & $0.197(0.017)$ & $-0.10(0.04)$ \\
\hline leaf fat & 0.53 & 0.14 & $0.71(0.05)$ & $0.01(0.09)$ & $-0.004(0.006)$ & $0.00(0.04)$ \\
\hline belly & 4.65 & 0.28 & $0.36(0.05)$ & $0.14(0.10)$ & $0.002(0.007)$ & $0.04(0.04)$ \\
\hline ham & 8.97 & 0.35 & $0.36(0.05)$ & $0.06(0.10)$ & $-0.001(0.003)$ & $0.02(0.03)$ \\
\hline shoulder & 4.98 & 0.24 & $0.22(0.04)$ & $-0.18(0.12)$ & $-0.024(0.008)$ & $-0.04(0.03)$ \\
\hline loin & 10.6 & 0.53 & $0.50(0.05)$ & $0.05(0.10)$ & $-0.066(0.012)$ & $0.02(0.04)$ \\
\hline $\begin{array}{l}\text { Lean meat } \\
\text { content }(\%)\end{array}$ & 50.7 & 2.7 & $0.68(0.04)$ & $0.18(0.09)$ & $-0.37(0.07)$ & $0.07(0.04)$ \\
\hline $\begin{array}{l}\text { Ham lean } \\
\text { percentage (\%) }\end{array}$ & 64.2 & 4.3 & $0.89(0.10)$ & $0.28(0.05)$ & $-0.44(0.07)$ & $0.13(0.05)$ \\
\hline $\begin{array}{l}\text { Loin eye } \\
\text { area }\left(\mathrm{cm}^{2}\right)\end{array}$ & 40.1 & 4.9 & $0.33(0.10)$ & $0.49(0.15)$ & $-0.37(0.06)$ & $0.14(0.05)$ \\
\hline
\end{tabular}

${ }^{\mathrm{a}} \mu$ : estimate of phenotypic mean; ${ }^{\mathrm{b}} \sigma_{p}$ : estimate of phenotypic standard deviation; ${ }^{\mathrm{c}} \mathrm{h}^{2}$ : estimate of heritability (SE in brackets); ${ }^{\mathrm{d}} \mathrm{r}_{\mathrm{A}}$ : estimate of genetic correlation with IVGP (SE in brackets); ${ }^{\mathrm{e}} \mathrm{R}$ : estimated response to selection per generation in physical units of the trait; ${ }^{\mathrm{f}} \mathrm{Co}-\mathrm{h}^{2}$ : estimated coheritability with IVGP (SE in brackets).

\section{DISCUSSION}

\subsection{Growth and carcass composition traits}

For most growth and carcass composition traits, the heritability values found here are in agreement with the average values reported from the literature by 


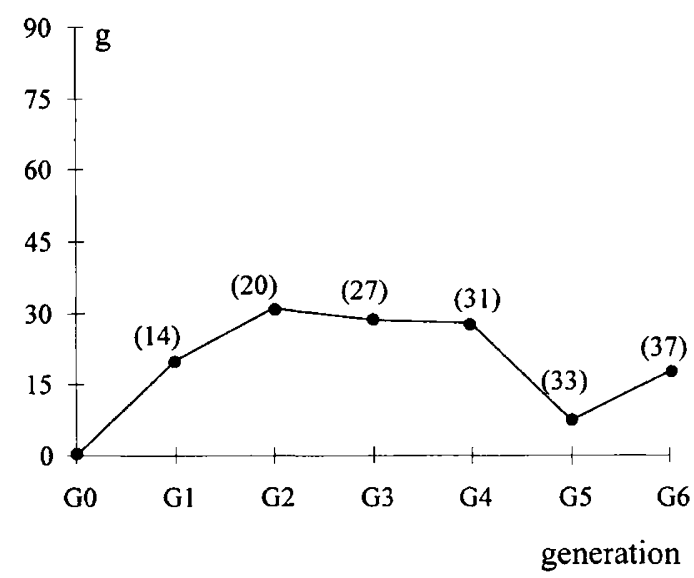

Figure 1. Genetic trend in average daily gain in the selected (S) line compared with the control (C) line (in brackets, standard errors of the $\mathrm{S}-\mathrm{C}$ estimates).

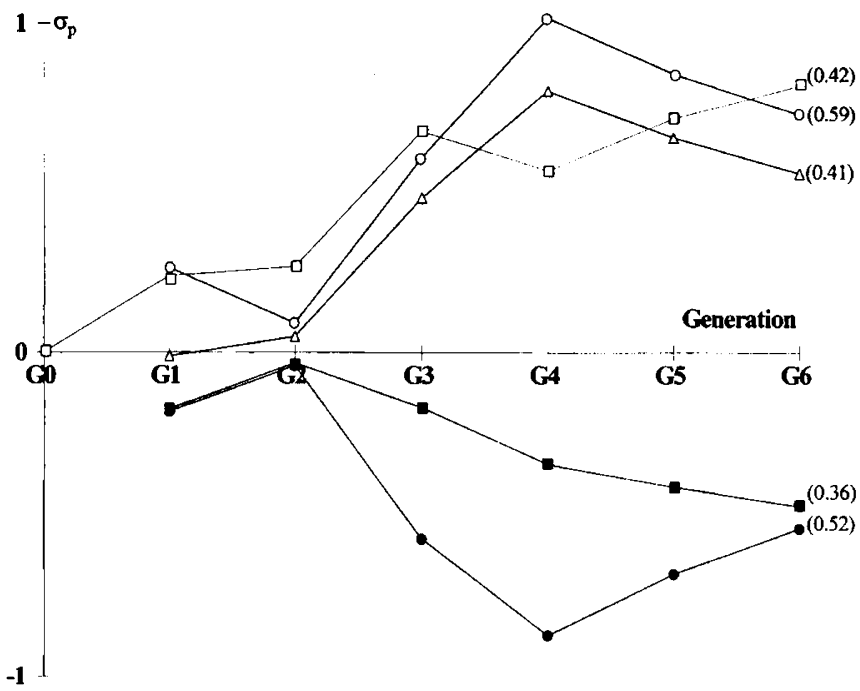

Figure 2. Genetic trend in carcass composition traits in the selected line compared with the control line, in phenotypic standard deviation units of each trait (in brackets, standard errors of the $\mathrm{S}-\mathrm{C}$ estimates at the generation 6 ). $\rightarrow-$, ultrasonic backfat thickness; $-\infty$, backfat weight; $-\triangle-$, average carcass backfat thickness; $\longrightarrow$, carcass lean meat content; $\rightarrow-$, loin eye area.

Ducos [5]. Our heritability estimate for dressing percentage (0.11) is noticeably lower than the average literature value of 0.36 [5] or the recently estimated values (0.39-0.54) in the French Large White breed [1, 6, 14, 33]. This low heritability of dressing percentage is probably due to the fact that the slaughter live weight was recorded before food withdrawal in the present study, whereas it was recorded on fasted animals in the other studies. 
Table III. Phenotypic and genetic parameters, correlated genetic responses to selection for reduced IVGP, and coheritabilities with IVGP for reproductive traits.

\begin{tabular}{|c|c|c|c|c|c|c|}
\hline Trait & $\mu^{\mathrm{a}}$ & $\sigma_{\mathrm{p}}^{\mathrm{b}}$ & $h^{2 c}$ & $r_{A}{ }^{d}$ & $\mathrm{R}^{\mathrm{e}}$ & $\mathrm{Co}-\mathrm{h}^{2 \mathrm{f}}$ \\
\hline $\begin{array}{l}\text { Age at first } \\
\text { oestrus }\end{array}$ & 217 & 22 & $0.32(0.05)$ & $-0.29(0.11)$ & $2.0(0.4)$ & $-0.08(0.03)$ \\
\hline \multicolumn{7}{|l|}{ Litter size } \\
\hline \multicolumn{7}{|l|}{ Total born } \\
\hline 1st parity & 10.2 & 2.8 & $0.15(0.06)$ & $-0.11(0.13)$ & $0.019(0.019)$ & $-0.02(0.02)$ \\
\hline 2nd parity & 9.8 & 2.6 & $0.03(0.02)$ & $-0.13(0.24)$ & $0.021(0.006)$ & $-0.01(0.02)$ \\
\hline \multicolumn{7}{|l|}{ Born alive } \\
\hline 1st parity & 9.6 & 3.0 & $0.09(0.06)$ & $-0.12(0.14)$ & $0.036(0.010)$ & $-0.02(0.02)$ \\
\hline 2nd parity & 9.4 & 2.7 & $0.02(0.02)$ & $-0.12(0.21)$ & $0.025(0.005)$ & $-0.02(0.02)$ \\
\hline \multicolumn{7}{|l|}{ Weaned } \\
\hline 1st parity & 7.9 & 2.9 & $n e^{g}$ & ne & ne & ne \\
\hline 2nd parity & 8.4 & 2.7 & ne & ne & ne & ne \\
\hline \multicolumn{7}{|c|}{ Litter weight $(\mathrm{kg})$} \\
\hline \multicolumn{7}{|l|}{ At birth } \\
\hline 1st parity & 12.2 & 3.4 & $0.24(0.06)$ & $0.00(0.07)$ & $0.12(0.04)$ & $0.00(0.02)$ \\
\hline 2nd parity & 13.2 & 3.4 & $0.10(0.04)$ & $0.12(0.15)$ & $0.08(0.03)$ & $0.02(0.02)$ \\
\hline \multicolumn{7}{|l|}{ At 21 days } \\
\hline 1st parity & 47.3 & 12.0 & $0.28(0.06)$ & $0.11(0.11)$ & $0.32(0.19)$ & $0.03(0.03)$ \\
\hline 2nd parity & 53.1 & 11.9 & $0.32(0.07)$ & $0.11(0.11)$ & $0.23(0.11)$ & $0.03(0.03)$ \\
\hline \multicolumn{7}{|l|}{ At weaning } \\
\hline 1st parity & 62.8 & 15.6 & $0.06(0.03)$ & $0.37(0.17)$ & $-0.05(0.19)$ & $0.04(0.02)$ \\
\hline 2nd parity & 69.6 & 15.2 & $0.34(0.09)$ & $0.13(0.12)$ & $0.40(0.16)$ & $0.04(0.04)$ \\
\hline
\end{tabular}

${ }^{\mathrm{a}} \mu$ : estimate of phenotypic mean; ${ }^{\mathrm{b}} \sigma_{\mathrm{p}}$ : estimate of phenotypic standard deviation; ${ }^{c} \mathrm{~h}^{2}$ : estimate of heritability (SE in brackets); ${ }^{d} \mathrm{r}_{\mathrm{A}}$ : estimate of genetic correlation with IVGP (SE in brackets); ${ }^{e} \mathrm{R}$ : estimated response to selection per generation in physical units of the trait; ${ }^{f} \mathrm{Co}-\mathrm{h}^{2}$ : estimated coheritability with IVGP (SE in brackets); ${ }^{\mathrm{g}}$ ne: not estimable.

The present estimate of genetic correlation and coheritability between in vivo glycolytic potential and average daily gain is of small magnitude but positive, which should have led to a decreased growth rate in the selected line. In fact, the genetic trend in average daily gain shows a slight increase in the selected line compared with the control line. Detailed examination of the genetic trend in this trait in the selected line shows that the average daily gain increased in the first two generations, while selection on IVGP was not very efficient [20]. From generation three onwards, the mean genetic value of average daily gain remained approximately constant in the selected line. Previously, Le Roy et al. [18] found no significant genetic correlation between IVGP and time on test from 20 to $100 \mathrm{~kg}$ live weight in two composite lines where the $\mathrm{RN}^{-}$and $\mathrm{rn}^{+}$ alleles were segregating.

All estimates of genetic correlations and genetic trends show an increase in carcass fatness, as a correlated response to downward selection on IVGP. The 
most pronounced trend was found for average backfat thickness measured on the live animal: at the sixth generation, the difference between the mean genetic values of the two lines reached nearly one phenotypic standard deviation unit of the trait. This result was in agreement with the value of the coheritability of this trait with IVGP which was one of the highest (in absolute value, with the lowest standard error). The genetic trend in carcass backfat thickness is similar to that in ultrasonic backfat thickness, though being of smaller magnitude (half a phenotypic standard deviation unit of the trait at the sixth generation). The genetic correlation found in the present study between IVGP and ultrasonic backfat thickness $(-0.32)$ was higher (in absolute value) than the genetic correlation $(-0.10)$ estimated between both traits in composite lines in which the $\mathrm{RN}^{-}$allele was segregating [18]. It is worth pointing out that the correlated genetic trend toward a higher carcass fatness in the selected line is in agreement with the differences previously reported between RN genotypes [7, 19]. Indeed, $\mathrm{rn}^{+} \mathrm{rn}^{+}$animals exhibit both lower muscle glycolytic potential and higher carcass fatness than $\mathrm{RN}^{-} \mathrm{RN}^{-}$and $\mathrm{RN}^{-} \mathrm{rn}^{+}$animals. The moderately unfavourable genetic relationship found here between IVGP and carcass lean to fat ratio is also in line with the moderately unfavourable genetic relationships previously found between carcass lean to fat ratio and technological meat quality criteria such as ultimate $\mathrm{pH}$, colour, drip loss and meat quality index in the French Large White $[3,6,14,33]$, and in other European Large White or Yorkshire populations $[4,12,13]$.

\subsection{Reproductive traits}

The present heritability estimate for age at first oestrus of gilts is in close agreement with the average literature value of $0.32-0.33[15,26]$, and is very close to the value of 0.29 recently found in the French Large White breed [2]. As there were some discrepancies between genetic parameters estimated for firstand second-parity litter traits, we have considered these traits as genetically different, instead of considering them as repeated measurements of the same trait. The heritability values estimated for first-parity litter size at birth $(0.09$ or 0.15 ) were within the range of those reported in the literature [9, 26]. Irgang et al. [11] showed that heritability values for litter size at birth or at 21 days were higher for second-parity than for first-parity litters. They also found a fairly weak genetic correlation between measurements made on first-parity and second-parity litters for those traits $(0.32-0.46)$. Our heritability value for firstparity litter weight at birth is in agreement with the average literature value of 0.29 reported by Lamberson [15] for the same trait, whereas the present heritability value for litter weight at 21 days, close to 0.30 for both parities, is higher than the average literature value of 0.17 reported by Rothschild and Bidanel [26]. There is an unexpectedly low heritability value for first-parity litter weight at weaning (i.e. at 28 days of age) compared with the heritability of first-parity litter weight at 21 days. When considering the same trait for second-parity litters, the heritability values are similar ( 0.32 and 0.34 for weight at 21 days and at weaning, respectively).

There are very few studies dealing with genetic relationships between reproductive traits and meat quality in pigs. Hermesch et al. [10] found a negative genetic correlation $(-0.34)$ between number of piglets born alive in 
first-parity litters and ultimate $\mathrm{pH}$, but this correlation was not confirmed for the number of piglets born alive in second- and third-parity litters $(0.10$ and -0.11 , respectively). Considering the estimates of genetic correlations of reproductive traits with IVGP, the standard errors of these estimates and the coheritabilities with IVGP, it may be concluded that selection on meat quality would have little effect on reproductive performance. The only trait which could be affected by selection on muscle glycolytic potential would be age at first oestrus in gilts $\left(\mathrm{Co}-\mathrm{h}^{2}=-0.08 \pm 0.03\right)$.

\section{CONCLUSION}

As far as growth rate, carcass composition and reproductive traits are concerned, the most striking correlated response to downward selection on muscle glycolytic potential is the significant decrease of carcass lean content or increase of carcass fatness. It should be pointed out that this genetic relationship appears to be expressed whatever the origin of the genetic variation in muscle glycolytic potential, either polygenic as investigated in the present selection experiment or due to the single major gene RN. A prospective study [16] has shown that it is possible to include IVGP as a selection criterion for improving technological meat quality in pig breeding programmes.

\section{ACKNOWLEDGEMENTS}

This work was part of the project 'Régulation du potentiel glycolytique du muscle chez le porc' and was supported by grants from the Inra-Agrobio programme initiated in 1990. Thanks are due to Pierre Vernin (Station de recherches sur la viande, Theix), Hervé Lagant (Station de génétique quantitative et appliquée, Jouy-en-Josas) and the staff of the pig experimental unit in Bourges-Avord for their technical assistance.

\section{REFERENCES}

[1] Bidanel J.P., Ducos A., Genetic correlations between test station and on-farm performance traits in Large White and French Landrace pig breeds, Livest. Prod. Sci. 45 (1996) 55-62.

[2] Bidanel J.P., Gruand J., Legault C., Genetic variability of age and weight at puberty, ovulation rate and embryo survival in gilts and relations with production traits, Genet. Sel. Evol. 28 (1996) 103-115.

[3] Cole G., Le Hénaff G., Sellier P., Paramètres génétiques de quelques caractères de qualité de la viande dans les races porcines Large White, Landrace français et Landrace belge, in: $20^{\mathrm{es}}$ Journées de la recherche porcine en France, Paris, 2-4 février 1988, Institut technique du porc, Paris, 1988, pp. 249-254.

[4] De Vries A.G., van der Wal P.G., Long T., Eikelenboom G., Merks J.M.W., Genetic parameters of pork quality and production traits in Yorkshire populations, Livest. Prod. Sci. 40 (1994) 277-289.

[5] Ducos A., Paramètres génétiques des caractères de production chez le porc. Mise au point bibliographique, Techni-porc 17(3) (1994) 35-67.

[6] Ducos A., Bidanel J.P., Ducrocq V., Boichard D., Groeneveld E., Multivariate restricted maximum likelihood estimation of genetic parameters for growth, carcass and meat quality traits in French Large White and French Landrace pigs, Genet. Sel. Evol. 25 (1993) 475-493. 
[7] Enfält A.C., Lundström K., Hansson I., Johansen S., Nyström P.E., Comparison of non-carriers and heterozygous carriers of the $\mathrm{RN}^{-}$allele for carcass composition, muscle distribution and technological meat quality in Hampshire-sired pigs, Livest. Prod. Sci 47 (1997) 221-229.

[8] Groeneveld E., Kovac M., A generalized computing procedure for setting up and solving mixed linear models, J. Dairy Sci. 73 (1990) 513-531.

[9] Haley C.S., Avalos E., Smith C., Selection for litter size in the pig, Anim. Breed. Abstr. 56 (1988) 317-332.

[10] Hermesch S., Luxford B.G., Graser H.-U., Genetic relationships between litter size and meat quality traits in Australian pigs, in: Proc. 46th Annual Meeting Eur. Assoc. Anim. Prod., Prague, Czech Republic, 1995.

[11] Irgang R., Favero J.A., Kennedy B.W., Genetic parameters for litter size of different parities in Duroc, Landrace, and Large White sows, J. Anim. Sci. 72 (1994) $2237-2246$.

[12] Johansson K., Evaluation of station testing of pigs. II. Multiple trait versus single trait estimation of genetic parameters for meat quality measurements, Acta Agric. Scand. 37 (1987) 108-119.

[13] Knapp P., Willam A., Sölkner J., Genetic parameters for lean meat content and meat quality traits in different pig breeds, Livest. Prod. Sci. 52 (1997) 69-73.

[14] Labroue F., Guéblez R., Sellier P., Genetic parameters of feeding behaviour and performance traits in group-housed Large White and French Landrace growing pigs, Genet. Sel. Evol. 29 (1997) 451-468.

[15] Lamberson W.R., Genetic parameters for reproductive traits, in: Young L.D. (Ed), Genetics of Swine, USDA-ARS, Clay Center, Nebraska, USA, 1990, pp. 70-76.

[16] Larzul C., Le Roy P., Sellier P., Jacquet B., Gogué J., Talmant A., Vernin P., Monin G., Le potentiel glycolytique du muscle mesuré sur le porc vivant : un nouveau critère de sélection pour la qualité de la viande? in: $30^{\text {es }}$ Journées de la recherche porcine en France, Paris, 3-5 février 1998, Institut technique du porc, Paris, 1998, pp. 81-85.

[17] Larzul C., Le Roy P., Gogué J., Talmant A., Jacquet B., Lefaucheur L., Ecolan P., Sellier P., Monin G., Selection for reduced muscle glycolytic potential in Large White pigs. II. Correlated responses in meat quality and muscle compositional traits, Genet. Sel. Evol. 31 (1999) 61-76.

[18] Le Roy P., Przybylski W., Burlot T., Bazin C., Lagant H., Monin G., Étude des relations entre le potentiel glycolytique du muscle et les caractères de production dans les lignées Laconie et Penshire, in: $26^{\text {es }}$ Journées de la recherche porcine en France, Paris, 1-3 février 1994, Institut technique du porc, Paris, 1994, pp. 311-314.

[19] Le Roy P., Monin G., Elsen J.M., Caritez J.C., Talmant A., Lebret B., Lefaucheur L., Mourot J., Juin H., Sellier P., Effect of the RN genotype on growth and carcass traits in pigs, in: Proc. 47th EAAP Annual Meeting, Lillehammer, Norway, 1996.

[20] Le Roy P., Larzul C., Gogué J., Talmant A., Monin G., Sellier P., Selection for reduced muscle glycolytic potential in Large White pigs. I. Direct responses, Genet. Sel. Evol. 30 (1998) 469-480.

[21] Monin G., Sellier P., Pork of low technological quality with a normal rate of muscle $\mathrm{pH}$ fall in the immediate post mortem period: the case of the Hampshire breed, Meat Sci. 13 (1985) 49-63.

[22] Monin G., Sellier P., Bonneau M., Trente ans d'évolution de la notion de qualité de la carcasse et de la viande de porc, in: $30^{\mathrm{es}}$ Journées de la recherche porcine en France, Paris, 3-5 février 1998, Institut technique du porc, Paris, 1998, pp. 13-27. 
[23] Neumaier A., Groeneveld E., Restricted maximum likelihood estimation in sparse linear models, Genet. Sel. Evol. 30 (1998) 3-26.

[24] Ollivier L., L'épreuve de la descendance chez le porc Large White français de 1953 à 1966. I. Analyse de la variation, Ann. Génét. Sél. Anim. 2 (1970) 311-324.

[25] Ollivier L., Lagant H., Gruand J., Molénat M., Progrès génétique des porcs Large White et Landrace français de 1977 à 1987, in: $23^{\text {es }}$ Journées de la recherche porcine en France, Paris, 5-7 février 1991, Institut technique du porc, Paris, 1991, pp. 389-394.

[26] Rothschild M.F., Bidanel J.P., Biology and genetics of reproduction, in: Rothschild M.F., Ruvinski A. (Eds.), The Genetics of the Pig, CAB International, Wallingford, Oxon, UK, 1998, pp. 313--343.

[27] SAS ${ }^{\circledR}$, SAS User's Guide: Statistics (Version 5 Ed.), SAS Inst Inc, Cary, NC, 1985.

[28] Searle S.R.; Casella G., Mc Culloch C.E., Variance Components, John Wiley \& Sons, New York, NY, 1992.

[29] Sellier P., Valeur en croisement de verrats Large White et Piétrain: influence du poids d'abattage, in: $9^{\text {es }}$ Journées de la recherche porcine en France, Paris, 2-3 février 1977, Institut technique du porc, Paris, 1977, pp. 85-89.

[30] Sellier P., L'amélioration génétique des performances de production du porc, C.R. Acad. Agric. Fr. 74 (1988) 23-38.

[31] Sorensen D.A., Kennedy B.W., Analysis of selection experiments using mixed model methodology, J. Anim. Sci. 63 (1986) 245-258.

[32] Talmant A., Fernandez X., Sellier P., Monin G., Glycolytic potential in Longissimus dorsi muscle of Large-White pigs as measured after in vivo sampling, in: Proc. 35th Int. Cong. Meat Sci. Technol., Copenhagen, Denmark, 1989, pp. 1129 1131.

[33] Tribout T., Garreau H., Bidanel J.P., Paramètres génétiques de quelques caractères de qualité de la viande dans les races porcines Large White et Landrace français, in: $28^{\mathrm{es}}$ Journées de la recherche porcine en France, Paris, 30 janvier -1 février 1996, Institut technique du porc, Paris, 1996, pp. 31-38. 